\title{
Estimation of Metabolism Characteristics for Heat-Injured Bacteria Using Dielectrophoretic Impedance Measurement Method
}

\author{
Eri Amako Non-member (Tokyo Metropolitan Univ.) \\ Takaharu Enjoji Non-member (Tokyo Metropolitan Univ., enjoji-takaharu@ed.tmu.ac.jp) \\ Satoshi Uchida Member (Tokyo Metropolitan Univ., s-uchida@tmu.ac.jp) \\ Fumiyoshi Tochikubo Member (Tokyo Metropolitan Univ., tochi@tmu.ac.jp)
}

Keywords : dielectrophoresis, impedance measurement method, metabolism activity, heat-injured bacteria, micro-cell

Constant monitoring and immediate control of fermentation processes have been required for advanced quality preservation in food industry. Dielectrophoretic technique is one of most effective electrical methods to detect the biological changes simply and rapidly. In recent studies, we developed an evaluation method for metabolism activity of fermentation microorganisms using dielectrophoretic impedance measurement (DEPIM) and dielectric characteristics of injured Escherichia coli (E. coli) with heat treatment stress were analyzed in a micro-cell with interdigitated electrode array. Especially, change of conductance between electrodes $(\Delta G)$ was investigated in various driving frequencies of the power supply. At a driving frequency of $100 \mathrm{kHz}$, each $\Delta \mathrm{G}$ of $E$. coli differed widely for heat treatment temperature. This result suggested that the conductivity of $E$. coli was largely changed by heat-treatment stress. However, quantitative correlation between the electrical change and biological activity had not been obtained at that time.

In the present work, metabolic states for heat-injured E. coli in micro-cell was simply estimated using DEPIM method. $\Delta G$ between electrodes was remeasured in the controlled-temperature suspension for various heat treatment temperatures. In addition, the dependence of enzyme activity, growth capacity and membrane situation for $E$. coli on heat treatment temperature was also analyzed with conventional biological methods.

The present experimental apparatus for DEPIM system is shown in Fig. 1. The fundamental setup is almost same as that used in our previous experiment. A temperature-controlled stirrer was newly added because influence of external heating on suspension was excluded. Spectrophotometer and scanning electron microscope were used for measurement of fluorescence strength and observation of membrane situation for heat-injured E. coli.

Figure 2 shows the relationship between heat treatment temperature and various experiments. Each experiment result was normalized with the maximum value in all of heat treatment temperature conditions. Therefore, the Y-axis is shown in no dimension. In the heat treatment temperature range between $277 \mathrm{~K}$ and $293 \mathrm{~K}, \Delta G$ tended to increase gently. $\Delta G$ decreased obviously over $293 \mathrm{~K}$. Finally, bacteria were completely inactivated and $\Delta G$ changed hardly at a treatment temperature of $353 \mathrm{~K}$. The enzyme activity reaction using cyanoditoyl tetrazolium chloride formazan (CTF) fluorescent method became highest at adequate temperature between 309 and $320 \mathrm{~K}$ that $E$. coli is actively cultured. In $E$. coli colony counts method by an agar nutrient medium as growth capacity test, the number of colonies changed hardly between 277 $\mathrm{K}$ and $309 \mathrm{~K}$ heat treatment temperature, whereas in over $328 \mathrm{~K}$, the number of colonies decreased dramatically. This means that $E$. coli can not grow on an agar nutrient medium over $328 \mathrm{~K}$. In addition, the membrane activity was reduced on "LIVE/DEAD" fluorescent test.

Consequently, a correlation between $\Delta G$ and those biological properties was obtained quantitatively. This result suggests that DEPIM method will be available for an effective monitoring method for complex change in various biological states of microorganisms.

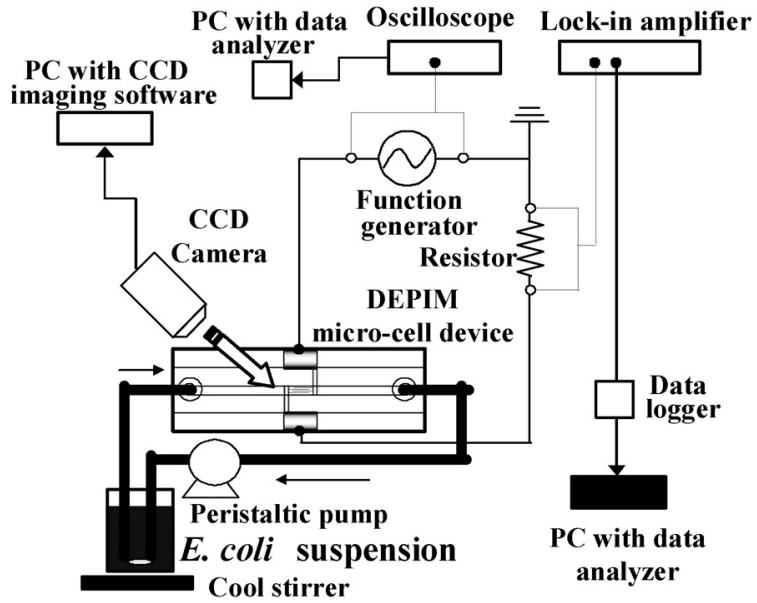

Fig. 1. Schematic diagram of the present experimental apparatus for DEPIM system

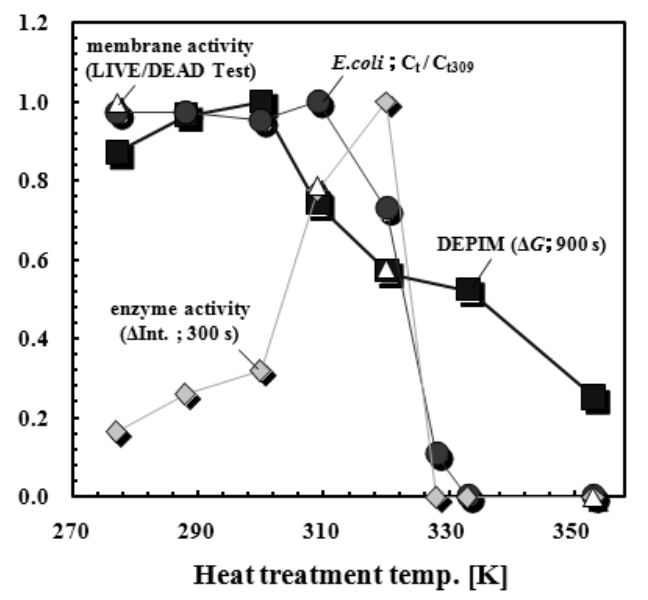

Fig. 2. Relative change in DEPIM and various biological experiments as a function of heat treatment temperature 


\title{
誘電泳動インピーダンス計測法を応用した 熱損傷菌の代謝評価に関する基礎検討
}

\author{
非会員 尼子 恵里* 非会員 円城寺隆治* \\ 正員 内田＼cjkstart諭* 正 員 杤久保文嘉*
}

\section{Estimation of Metabolism Characteristics for Heat-Injured Bacteria Using Dielectrophoretic Impedance Measurement Method}

Eri Amako*, Non-member, Takaharu Enjoji*, Non-member, Satoshi Uchida*, Member, Fumiyoshi Tochikubo*, Member

Constant monitoring and immediate control of fermentation processes have been required for advanced quality preservation in food industry. In the present work, simple estimation of metabolic states for heat-injured Escherichia coli (E. coli) in a micro-cell was investigated using dielectrophoretic impedance measurement (DEPIM) method. Temporal change in the conductance between micro-gap $(\Delta G)$ was measured for various heat treatment temperatures. In addition, the dependence of enzyme activity, growth capacity and membrane situation for E. coli on heat treatment temperature was also analyzed with conventional biological methods. Consequently, a correlation between $\Delta G$ and those biological properties was obtained quantitatively. This result suggests that DEPIM method will be available for an effective monitoring technique for complex change in various biological states of microorganisms.

キーワード : 誘電泳動, インピーダンス計測法, 代謝活性, 熱損傷菌, マイクロセル

Keywords : dielectrophoresis, impedance measurement method, metabolism activity, heat-injured bacteria, micro-cell

\section{1. はじめに}

酒造業や乳加工業において，発酵工程は品質保持の観点 から最重要項目に挙げられる。しかしながら, その工程の 多くは経験的知見に基づいた定時管理を前提としており， 異常発生時の瞬時制御に対応していない。このため, 酵母 や乳酸菌の状態を工程内で連続的に計測し，フィードバッ ク制御できる新たなシステムの開発が望まれている。

上記システムの構築には迅速かつ簡便な菌計測が必須で ある。電気計測法の一つである誘電泳動法 ${ }^{(1)(2)}$ は，原理的に 高速性と簡易性を兼坟備えた有力な手法であり，誘電特性 の違いによる菌種分離や生死菌判定に利用されている。ま た, 細菌群の橋絡による電極間のインピーダンス変化を利 用した誘電泳動インピーダンス計測 (dielectrophoretic impedance measurement: DEPIM) 法 ${ }^{(3)}$ では, 菌密度計測 ${ }^{(4)(5)}$ も可能である。一方，代謝活性については，微生物懸濁液 の誘電率変化 ${ }^{(6)(7)}$ や微生物の成長過程における誘電特性の 変動 ${ }^{(8)}$ から間接的に評価した事例が報告されている。しかし

\footnotetext{
* 首都大学東京 (東京都立大学)

干192-0397 東京都八王子市南大沢 1-1

Tokyo Metropolitan University,

1-1 Minami-Oosawa, Hachioji-shi, Tokyo, 192-0397
}

ながら, 菌の生物学的状態と誘電泳動時における電極間イ ンピーダンスの変化との直接的な相関については, 十分な 知見が得られていない。

そこで著者らは, 酵母や乳酸菌などの発酵菌の代謝活性 評価を行う基礎段階として, 加温処理により代謝状態の異 なる大腸菌 (Escherichia coli: E. coli) を実験的に調整し，駆 動周波数に対する DEPIM の処理温度依存性を精査した ${ }^{(9)}$ 。 電極間コンダクタンスの経時変化は，低周波数において処 理温度の影響を受けることがわかり，その結果から，加温 処理による大腸菌の誘電特性変化は, 導電率の変動が支配 的であると推察された。

本報では, さらに生物学的手法を用いて, 膜損傷および 代謝活性度の処理温度依存性を解析し, DEPIM 法によるイ ンピーダンス変化との相関を検討した。結果として, 菌の 生死, 膜損傷および呼吸活性の複合的変化がインピーダン ス変動に反映されており, 代謝活性を含む菌の生物学的変 化を定量的に捉えることができた。本研究成果は, DEPIM 法を導入することによって, 発酵菌に対する実用的な計測 システムの構築が可能であることを示唆している。 


\section{2. 誘電泳動理論}

誘電泳動 (Dielectrophoresis: DEP) とは，不平等電界中に 置かれた誘電微粒子において, 粒子の対極に形成される電 界強度の差に応じて，双極子モーメントが作用する現象で ある ${ }^{(10) \sim(12)}$ 。不平等電界下における誘電泳動力 $F_{\mathrm{dep}}$ は, 次式 で与えられる。

$$
F_{\text {dep }}=2 \pi \varepsilon_{1} \operatorname{Re}[\hat{K}(\omega)] R^{3} \nabla E_{0}^{2}
$$

ここで， $R$ は粒子半径， $E_{0}$ は電界である。 $\hat{K}(\omega)$ は，

$$
\begin{aligned}
\hat{K}(\omega) & =\frac{\hat{\varepsilon}_{2}-\hat{\varepsilon}_{1}}{\hat{\varepsilon}_{2}+2 \hat{\varepsilon}_{1}} \\
& =\frac{\varepsilon_{2}-\varepsilon_{1}-j\left(\sigma_{2}-\sigma_{1}\right) / \omega}{\varepsilon_{2}+2 \varepsilon_{1}-j\left(\sigma_{2}+2 \sigma_{1}\right) / \omega}
\end{aligned}
$$

で与えられる交流電界 (角周波数 $\omega$ ) での Clausius-Mossotti 関数である。なお， $\hat{\varepsilon}$ は複素誘電率， $\varepsilon$ は誘電率， $\sigma$ は導電 率であり，添字 1 及び 2 はそれぞれ媒質及び粒子を意味す る。上式より, $F_{\text {dep }}$ は電界分布, 電界周波数, 媒質及び粒子 の複素誘電率，さらに粒子径に依存する事が分かる。

菌眯濁液において，不平等電界が生じるように配置され た微小電極に電圧が印加されると, 細菌は誘電泳動力によ つて電極間に捕集される。結果として, 濃縮された細菌群 は，電極間のインピーダンス（またはコンダクタンス）変 化として検出される。本手法のことをDEPIM 法(13) と呼んで いる。

\section{3. 実験装置及び実験方法}

〈3·1〉誘電泳動マイクロフィルタ＼cjkstart本実験において は, 誘電泳動力を効果的に発生させるマイクロセル（誘電 泳動マイクロフィルタ) を用いた。本フィルタは, $60 \mathrm{~mm}(\mathrm{~L})$ $\times 20 \mathrm{~mm}(\mathrm{~W}) \times 1.0 \mathrm{~mm}(\mathrm{~T})$ の石英基板上に蒸着形成したマ イクロ電極アレイ, 軟性ポリジメチルシロキサン製のマイ クロチャネル，及びアクリル製の電極セルホルダーからな る ${ }^{(9)}$ 。電極アレイにおける微生物捕集部は, $5.0 \mathrm{~mm}(\mathrm{~L}) \times 0.1$ $\mathrm{mm}(\mathrm{W}) \times 0.1 \mu \mathrm{m}(\mathrm{T})$ の $\mathrm{Cr}$ 電極 10 本を等間隔に並列配置し て, 同形の電極 10 本を対面から交互に組み合わせた櫛形電 極で構成されている。各電極の間隔は, $10 \mu \mathrm{m}$ である。流路 は $55 \mathrm{~mm}(\mathrm{~L}) \times 3 \mathrm{~mm}(\mathrm{~W}) \times 0.5 \mathrm{~mm}(\mathrm{~T})$ である。電極表面に は, 有機物の非特異的反応 (吸着) を抑制する界面親和剤 (主 成分：りん脂質) ${ }^{(14)}$ を塗布した。

〈3-2〉菌種及び調整方法対象菌種は, 大腸菌 Escherichia coli $\mathrm{K} 1$ 株 ATCC 11775 （以下，大腸菌）を用い た。大腸菌は, 大きさ $1-1.5 \times 2-6 \mu \mathrm{m}$ の通性嫌気性グラム 陰性桿菌である(15)。寒天培地上で増菌培養した大腸菌を滅 菌済み 0.15 M D-マンニトール $(\mathrm{DM})$ 溶液に混和したもの を懸濁原液とした。培地は標準寒天培地（日本製薬）を使 用し, $309 \mathrm{~K}\left(36^{\circ} \mathrm{C}\right), 24 \mathrm{~h}$ の条件で培養した。コロニーカ ウント法によって計測した結果, 菌密度は約 $8 \times 10^{8} \mathrm{CFU} / \mathrm{mL}$ であった。なお, 密度変化を抑制するため, 懸濁原液は 277 $\mathrm{K}\left(4^{\circ} \mathrm{C}\right)$ で保管した。
〈3·3〉加温処理工程本実験では, 代謝活性能力の 異なる菌を作製する手段として, 熱処理によるストレス負 荷を用いた。 $277 \mathrm{~K} て ゙$ 保管されていた懸濁原液 $1 \mathrm{~mL}$ を, 滅 菌済みスクリューキャップチューブに分取した後, 水温を $288 \mathrm{~K}-353 \mathrm{~K}\left(15^{\circ} \mathrm{C}-80^{\circ} \mathrm{C}\right)$ に設定したウォーターバス内で それぞれ $15 \mathrm{~min}$ 加温した。また, 低温時における大腸菌の 代謝活性変化を確認するため, $277 \mathrm{~K}$ の試料も検証した。

〈3.4〉誘電泳動特性計測加温処理を施した各試料 に対して誘電泳動を行い, 菌の捕集特性を電極間インピー ダンスの変化から定量的に測定した。DEPIM 実験装置の概 略を図 1 に示す。実験装置及び実験手順については, 過去 に行った一連の実験 ${ }^{(9)} に$ 準拠した。今回は更に恒温スターラ 一 (CSB-900N, AS ONE) を用い, 試料の温度制御及び攪拌 を行った。正弦波電圧印加開始から $90 \mathrm{sec}$ 後に加温処理大 腸菌サンプルを $299 \mathrm{~K}\left(26^{\circ} \mathrm{C}\right)$ の DM 溶液入りサンプルビン に注入し，900 secに達した時点で印加を停止した。送液ポ ンプの流量は $60 \mathrm{~mL} / \mathrm{h}$ とした。最終大腸菌䀣濁液密度は, 約 $3 \times 10^{7} \mathrm{CFU} / \mathrm{mL}$ となるようにした。

〈3.5〉 生物学的検証 加温処理による大腸菌の性状 への影響を, 生物学的手法により検証した。

（1）酵素活性酵素活性状態を評価するために cyanoditoyl tetrazolium chloride $\left(\mathrm{CTC}, \mathrm{C}_{16} \mathrm{H}_{14} \mathrm{ClN}_{5}\right)$ 染色を行 い, 近赤外分光蛍光光度計（FP-6600, 日本分光）を用いて 蛍光強度を測定した。CTC は呼吸活性に伴う電子伝達系の 作用で CTC formazan (CTF) に還元され ${ }^{(16)}$, 赤色蛍光性沈澱 として細胞内に蓄積する。そのため, 蛍光強度の増加が酵 素活性の高さを表わす。各処理サンプル $1 \mathrm{~mL}$ に $10 \mathrm{mM} \mathrm{CTC}$ 溶液 $0.5 \mathrm{~mL}$ を注入し, 攪挥後 $\mathrm{CTF}$ 蛍光強度変化を $900 \mathrm{sec}$ 連続測定した。なお, 励起及び蛍光波長のピークは, $554 \mathrm{~nm}$ 及び $604 \mathrm{~nm}$ である。

（2）生育能力 DM 溶液で $10^{6}-10^{7}$ 倍希釈した各処理 サンプル $1 \mathrm{~mL}$ を滅菌済みペトリ皿 2 枚ずつに分注し, 混釈 平板培養法によって生育する菌集落（コロニー）数から, 各処理サンプルの菌密度を算出した。培地及び条件は, 上

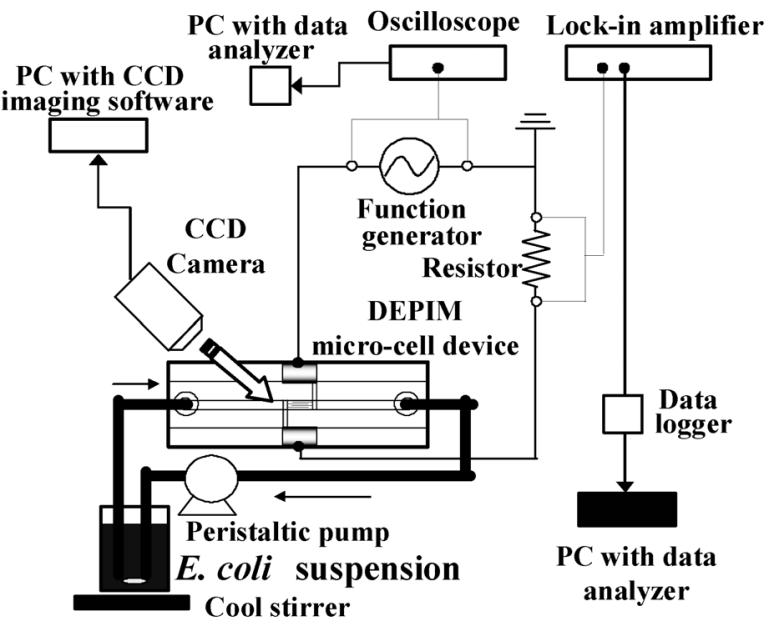

図 1 DEPIM 実験装置概略図

Fig. 1. Schematic diagram of DEPIM system 
記 $\langle 3 \cdot 3\rangle$ 節と同様とした。

（３）表面形状処理サンプルを, ポリカーボネートメ ンブランフィルタ（孔径 $0.2 \mu \mathrm{m}$, 東洋濾紙）上で固定, 脱 水, 乾燥, $\mathrm{Au}$ コーティング処理し ${ }^{(17)}$, 走查型電子顕微鏡 (scanning electron microscope: SEM, ERA8000, エリオニク ス）を用いて観察した。固定は $0.15 \mathrm{M}$ リン酸緩衝生理食塩 水で希釈した $1 \%$ グルタルアルデヒド固定液及び $1 \%$ 四酸化 オスミウム固定液を用いて，室温で各 $60 \mathrm{~min}$ 行った。脱水 は 30-100\%エタノール上昇系列を使用して，室温で各 10 $\min$ 行った。乾燥は $100 \%$ 第 3 級ブチルアルコールによる 置換後凍結乾燥法で行った。約 $350 \AA$ の膜厚になるように $\mathrm{Au}$ を蒸着し, 試料作成後 1 日以内に観察した。

(4) 生死及び膜状態 LIVE/DEAD ${ }^{\circledR}$ 染色キット (L13152, Invitrogen) を用いて染色を行い, 位相差生物蛍光顕 微鏡 $(\mathrm{E} 600, \mathrm{Nicon})$ で観察した。本キットは, $\mathrm{SYTO}^{\circledR} 9$ 及び propidium iodide (PI, $\mathrm{C}_{27} \mathrm{H}_{34} \mathrm{I}_{2} \mathrm{~N}_{4}$ ) の核酸染色剂からなり, 一 般に生死菌判別に用いられる(16)。菌に膜損傷がない場合, 膜透過性のある $\mathrm{SYTO}^{\circledR} 9$ の夕内部に取り込まれ, 核 DNA が 緑色に染色される。膜損傷がある場合, 膜透過性のない PI も内部に取り込まれ，核 DNA が赤色に染色される ${ }^{(16)}$ 。各処 理試料 $1 \mathrm{~mL}$ に, 純水で調整した LIVE/DEAD ${ }^{\circledR}$ 染色剂を同量 混和し， $\mathrm{SYTO}^{\circledR} 9$ は $6 \mu \mathrm{M}, \mathrm{PI}$ は $30 \mu \mathrm{M}$ を最終濃度とした。 遮光して $10 \mathrm{~min}$ 常温保管した試料をスライドガラス上に滴 下し観察した。顕微鏡観察時の蛍光色から膜状態及び生死 を判別した。

\section{4. 実験結果及び考察}

〈4・1〉誘電泳動実験結果 過去の実験結果から, 電 圧振幅 $5 \mathrm{~V}$, 電圧周波数 $100 \mathrm{kHz}$ においては, 電極間のコン ダクタンス変動の方がキャパシタンス変動よりも顕著であ ることがわかっている ${ }^{(9)}$ 。本実験でも同じ条件で，電圧印加 開始後からのコンダクタンス増加量 $\Delta G$ を計測し, 加温処理

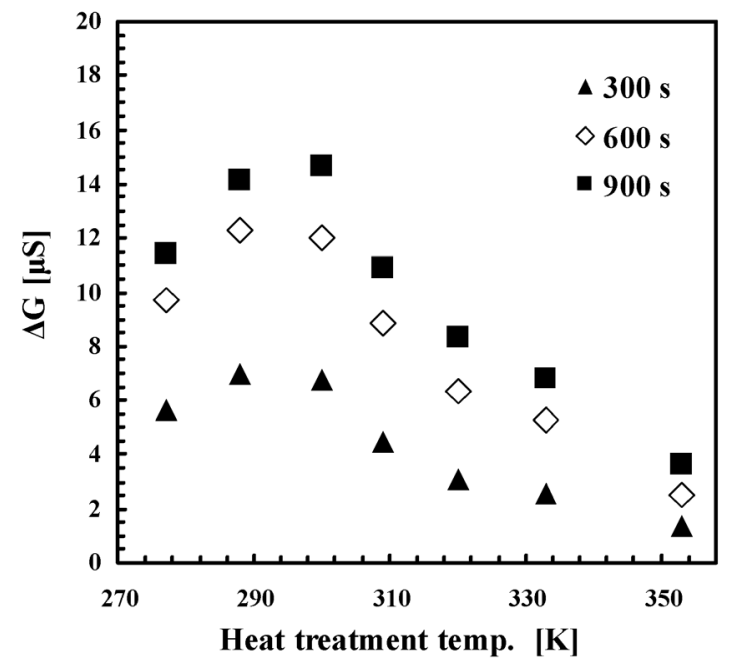

図 $2 \Delta G$ と処理温度の関係

Fig. 2. Relationship between $\Delta G$ and heat treatment temperature
温度に対する特性を評価した。図 2 に印加開始後 300, 600 及び $900 \mathrm{sec} に お け る$ 結果を示す。加温処理温度が $277 \mathrm{~K}$ $293 \mathrm{~K}$ の間では, その増加に伴い, $\Delta G$ も緩やかに増加して いる。 $293 \mathrm{~K}$ 以降は, 加温処理温度の増加上昇と共に $\Delta G$ は 低下し，完全に失活したと推測される $353 \mathrm{~K}$ では，大きな $\Delta G$ の上昇は見られなかった。

ここで, 単体の大腸菌をキャパシタンス $C_{\mathrm{e}}$ とコンダクタ ンス $G_{\mathrm{e}}$ を並列に持つ電気等価回路として考える。電極間に $m$ 個の大腸菌が直列に架橋してパールチェーンを形成し, さらに $x$ 本のパールチェーンが並列に形成された時の $\Delta G$ は以下で表される。

$$
\Delta G=\frac{x}{m} G_{e}
$$

ただし, $m$ は電極閒隔及び粒子径 $R$ に依存する。 $(3)$ 式より, $\Delta G$ は捕集される全菌数 $\mathrm{m} x$ および $G_{\mathrm{e}}$ に比例することがわか る。また, $\mathrm{m} x$ は $(2)$ 式の $F_{\mathrm{dep}}$ に依存し, $G_{\mathrm{e}}$ は菌の導電率に 比例する。

DEPIM 実験時の顕微鏡観察により, $\Delta G$ 変動は，電極間 で生じる菌の捕捉速度及び捕捉量の相違によって生じ, 高 温処理 $(353 \mathrm{~K})$ の場合, 電極間への捕集量が明らかに少な いことが確認された。通常, 生菌と死菌では誘電特性が大 きく異なる ${ }^{(1)}$ 。本実験においても，高温処理では膜破壊及び タンパク質変性などにより大腸菌の誘電率が変化し, $F_{\mathrm{dep}}$ が減少したと考えられる。一方, 死滅には至らない温度で は, 誘電率変化よりも導電率変化の方が大きいと推察され る。

〈4·2〉生物学的実験結果 図 3 に加温処理温度と $\mathrm{CTF}$ 蛍光強度の関係を示す。なお, 測定開始からの蛍光強 度の増加量を $\Delta$ Int. とした。 $277 \mathrm{~K}-309 \mathrm{~K}$ の範囲では加温処 理温度の増加に伴って $\Delta \mathrm{Int}$. も増加した。 $320 \mathrm{~K}\left(47^{\circ} \mathrm{C}\right)$ では $300 \mathrm{sec}$ 付近までは増加量が多いが最終的な $\Delta \mathrm{Int}$. は $309 \mathrm{~K}$ と 同程度であった。一方, 失活状態にある $333 \mathrm{~K}\left(60^{\circ} \mathrm{C}\right)$ 以上 での $\Delta$ Int. は 0 であった。測定時間内における蛍光強度の増

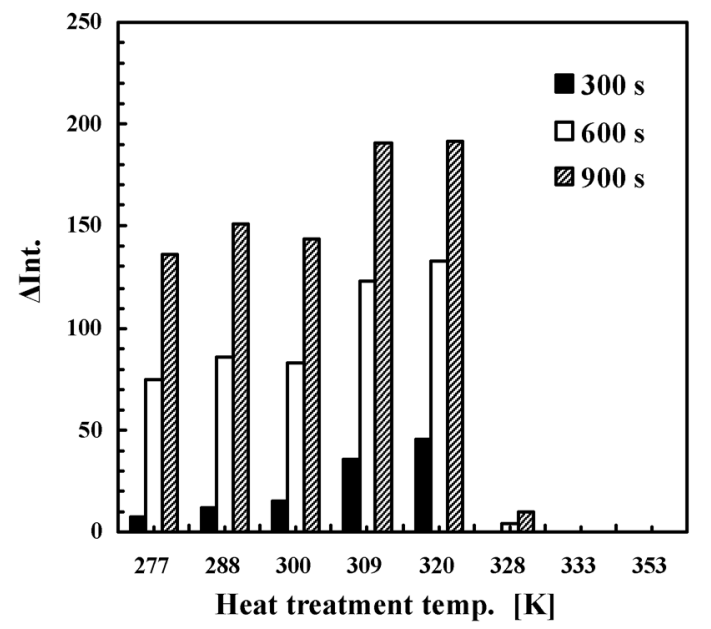

図 3 加温処理温度と $\mathrm{CTF}$ 蛍光強度の関係

Fig. 3. Relationship between CTF fluorescent strength and heat treatment temperature 


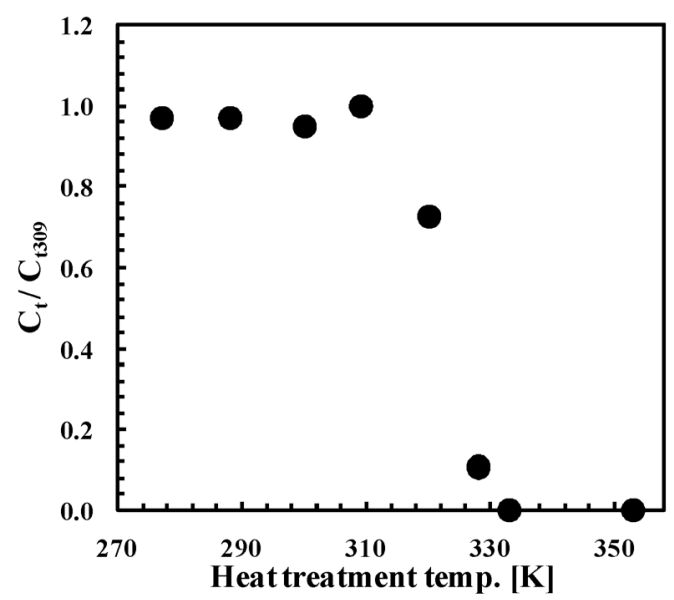

図 4 加温処理温度と大腸菌生育数の関係

Fig. 4. Relationship between E. coli counts and heat treatment temperature
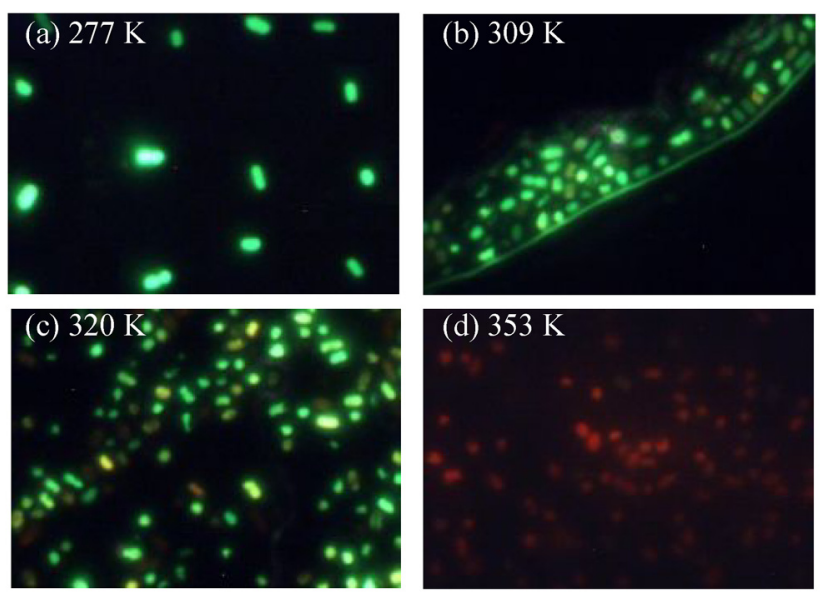

図 5 各温度で処理した大腸菌の LIVE/DEAD ${ }^{\circledR}$ 染色画像

Fig. 5. Image series of heat-treated E. coli dying by Live/Dead ${ }^{\circledR}$ BacLight $^{\mathrm{TM}}$ Bacterial Viability Kit

加は, CTC から分解生成した CTF 増加によるものであり, その増加量及び増加速度は，代謝能力及び菌数に依存する。 ゆえに，低温保管時 $(277 \mathrm{~K})$ では大腸菌の代謝機能を抑制 するが，大腸菌の至適生育温度範囲 $\left[303 \mathrm{~K}\left(30^{\circ} \mathrm{C}\right)-318 \mathrm{~K}\right.$ $\left.\left(45^{\circ} \mathrm{C}\right)\right]$ での加温処理は, 大腸菌の代謝機能を活性化させ ることがわかる。なお， $320 \mathrm{~K}$ では活性化した菌だけではな く, 損傷または死滅した菌が混在していると考えられる。

生育能力を比較するために, $309 \mathrm{~K}$ 時のコロニー数を基準 とした相対コロニー数 $\left(\mathrm{C}_{\mathrm{t}} / \mathrm{C}_{\mathrm{t} 309}\right)$ を図 4 に示す。 $277 \mathrm{~K}-309$ $\mathrm{K}$ の範囲ではコロニー数に大きな差異は見られず, 生育能 力が保持されていた。 $320 \mathrm{~K}$ における $\mathrm{C}_{\mathrm{t}} / \mathrm{C}_{\mathrm{t} 309}$ は 0.75 まで減 少し， $328 \mathrm{~K}\left(55^{\circ} \mathrm{C}\right)$ では 0.11 まで減少した。加温ストレス において, 負荷強度及び培地の種類によっては損傷から回 復し, 寒天培地上で生育するが ${ }^{(18)}, 333 \mathrm{~K}\left(60^{\circ} \mathrm{C}\right)$ 以上の処 理では回復できず, 細胞質膜等のタンパク質の熱変性, 或 いは細胞表面全体の著しい損傷によって代謝機能を失った
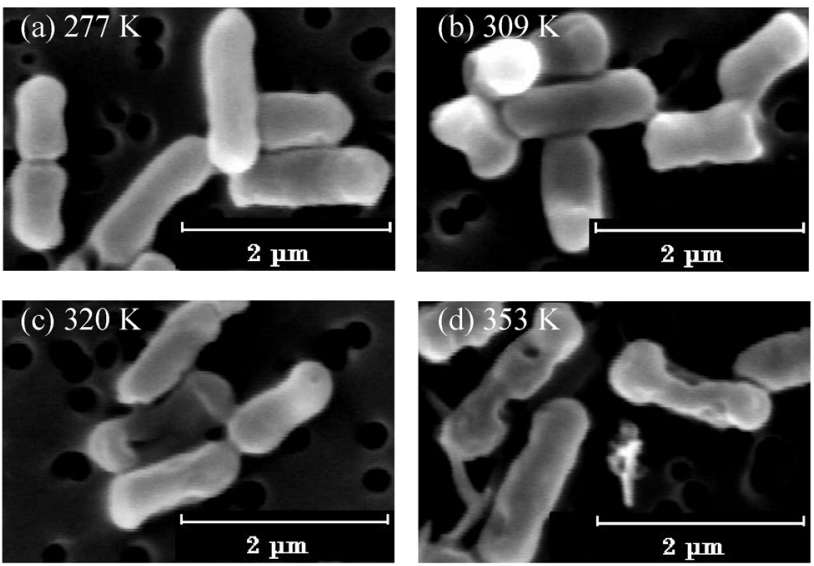

図 6 各温度で処理した大腸菌の SEM 画像

Fig. 6. SEM image series of heat treated E. coli.

と推測される。

図 5 に LIVE/DEAD ${ }^{\circledR}$ 染色画像を示す。 $277 \mathrm{~K}$ においては, PI 染色される大腸菌は見られず, 緑色に蛍光発色した大腸 菌のみ観察された（図 5(a)参照)。このことから，この温度 で処理された大腸菌の菌体表面は損傷していないことが分 かる。しかし, 図 5 (b)の $309 \mathrm{~K}$ 処理においては黄色または オレンジ色に近い蛍光発色している大腸菌が全体の $20 \%$ 程 度観察された。これは, 緑色に蛍光発色する $\mathrm{SYTO}^{\circledR} 9$ と同 時に, 赤色に蛍光発色する PI が取り込まれたためであり, 本加温処理において細胞膜に穿孔が生じたことを意味す る。本来, $309 \mathrm{~K}$ は至適生育温度範囲内であり, コロニーカ ウント結果による生育数にも変化は見られないが, 本実験 のように $277 \mathrm{~K}\left(4^{\circ} \mathrm{C}\right)$ で保管したサンプルを急速に加温す ることによって, 菌状態に多大な影響を及ぼすことが報告 されている(19)。このことから, $309 \mathrm{~K}$ では死滅には至らない が回復可能な膜損傷があると言える。図 5(c)の $320 \mathrm{~K}$ 処理で は赤色に発色している大腸菌も観察され, オレンジ色また は黄色に発色しているものと併せると, 約 45 \%が損傷した。 図 5(d)の $353 \mathrm{~K}$ 処理では全ての菌が赤色に発色しており, 細 胞膜が完全に破壊されていることを示す。

図 6 に示した SEM 観察結果では, $309 \mathrm{~K}$ において若干の 変形が確認された。さらに, 加温処理温度が $320 \mathrm{~K}$ 以上に なると, 表面に多数のくぼみ及びしわが発生し, 完全な失 活状態にある $353 \mathrm{~K}$ では, 表面的な変化に加え, 著しい菌 体収縮が見られた。これらの観察結果は $320 \mathrm{~K}$ 以上では加 温処理によって大腸菌が著しい損傷を受けたことを示唆し ている。

〈4·3〉 DEPIM と代謝活性の相関検討 本研究で得ら れた誘電泳動による電気的特性を評価するため, 生物学的 実験との相関を定量化した。図 7 に処理温度と各種実験の 規格化值の関係を示す。ここでは各処理温度における值を 実験毎の最大值で規格化した。酵素活性は CTF 発光強度か ら判定した。ただし, 経時による菌の活性低下及び加水分 解による菌に由来しない CTF 濃度上昇の影響を考慮し, 900 $\sec$ 連続測定のうち $300 \mathrm{sec}$ 時の值を規格化に用いた。膜損 


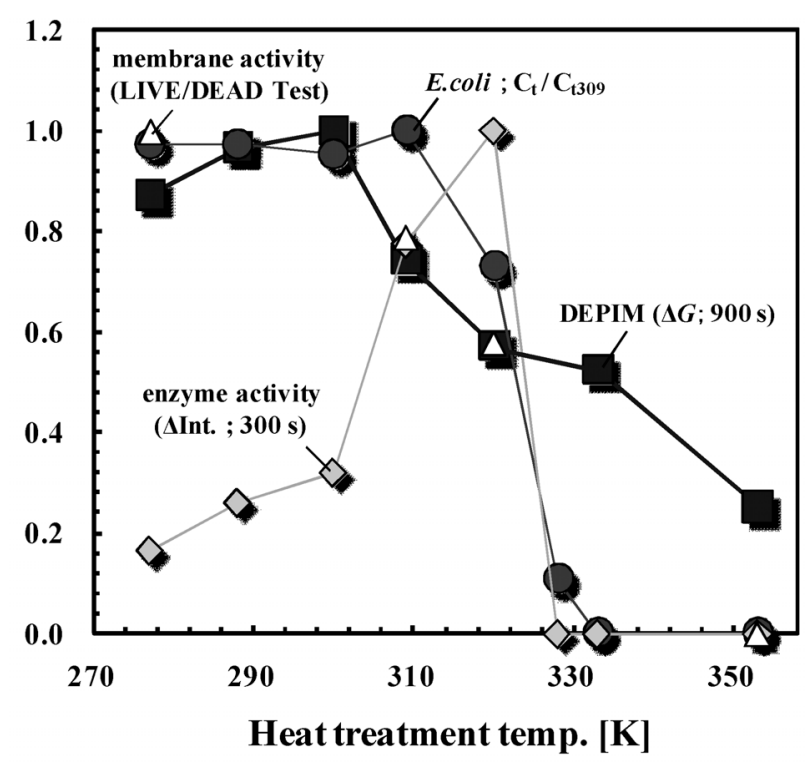

図 7 処理温度と各種実験結果の関係

Fig. 7. Relationship between heat treatment temperature and various experimental results

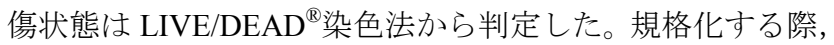
画像解析で得られた全菌数を分母とし, 生菌数（緑色に呈 色した菌）を分子で示した。

本実験でも確認されたが, 高温ストレス負荷は大腸菌外 層の細胞壁あるいはその内側にある細胞質膜を構成する夕 ンパク質の変性或いは破損を引き起こす。このような状態 では菌体内の各種イオンまたは核酸関連物質漏洩, 糖及び アミノ酸の基質輸送機能低下, 菌体内でのタンパク質凝集, 各種酵素失活などの諸現象 ${ }^{(18) \sim(21)}$ が生じる。一方, 低温ス卜 レス負荷では, 常温では形成されない二次構造が mRNA 上 に形成され，各種タンパク質の合成が阻害される。これら のストレスに適応するため, 菌体内ではタンパク質の正常 な二次構造形成を助けるシャペロンタンパク質や, 変性タ ンパク質を速やかに体外一排出するためのタンパク質分解 酵素等のストレス応答物質が合成される(21) (24)。さらに低温 では代謝活性が抑制され，膜がゲル化する。これに対応す るため細胞膜脂質中の不飽和脂肪酸の割合を増やして流動 性の高い状態を維持するなどのストレス応答が発生する。 凝集タンパク質，または不要になったストレス応答タンパ ク質等は, 分解されて菌体外に放出される(20)。

これら一般に知られている生化学的反応から, 今回得ら れた DEPIM 測定結果を考察すると，低温 $(277 \mathrm{~K}-300 \mathrm{~K})$ 領域における $\Delta G$ 変動は, 主に代謝 (酵素) 活性抑制によっ て惹起されたものと考えられ，このことは CTF 発光強度測 定によって確認された。その他, 低温ストレスに起因寸る 外部溶液 $(\mathrm{DM})$ の取込み速度変化及び膜組成・菌体内組成 変化による導電率の相違も, 変動要因として挙げられる。

一方, 高温（ $320 \mathrm{~K}$ 以上）に拈ける $\Delta G$ 変動は, 今回, コ ロニーカウント測定, 生死菌染色及び SEM 観察から得られ た知見から, 生菌数減少, 膜損傷・完全な膜破壊及び菌体
収縮などに起因する生死菌の複素誘電率の相違, 菌体内物 質漏洩による大腸菌及び外部溶液 (DM) の導電率の相違, または菌半径の相違によるものといえる。また, 至適生育 温度範囲内である $309 \mathrm{~K}$ における DEPIM 測定值の変動の主 要因は, 酵素活性化による体内組成変化に加え, 急激な加 温による形状変化, 膜損傷による菌体内物質漏洩により引 き起こされる導電率の相違が考えられる。この時, 図 6 よ り, DEPIM では酵素活性化の影響に比べ, 膜損傷による影 響をより大きく受けていることがわかる。以上のことから， DEPIM の結果は, 菌の代謝状態, 損傷度合い及び生死菌割 合などを複合的に評価しているといえる。

\section{5. まとめ}

誘電泳動インピーダンス計測 (DEPIM) 法を応用した微 生物の代謝活性評価システム構築を目的として, 我々はこ れまでに加温ストレス負荷大腸菌に対する DEPIM 実験を行 い, その処理温度依存性と周波数特性を調查した。本報で は, DEPIM におけるコンダクタンス変動要因を精查するた め, 各種生物学的実験を用いて, 加温ストレス負荷が大腸 菌に与える影響を調查した。その結果, DEPIM によるコン ダクタンス変動特性によって, 単に菌の生死だけではなく, 膜損傷状態や，ある種の代謝活性（呼吸活性）状態変化を 複合的に評価できることが分った。このことは, 菌の代謝 活性状態をリアルタイムでモニタリングできる可能性を示 唆している。更に, 電極セル形状の最適化やフィードバッ ク制御による処理温度の安定化を図れば, 精度の高い製造 ライン管理システムを構築することも可能である。

今後の課題として, 他の加温条件, 薬剤投与及び各 $\mathrm{pH}$ 緩 衝剂に対する菌の代謝活性変化と誘電泳動特性の相関を精 查する必要がある。また, RT-PCR 法による遺伝子レベルで の代謝変動検出, 導電率及び形状変化に伴う粒子挙動シミ ユレーションによる理論的解析も必須である。今回は比較 的扱いが容易な大腸菌を実験菌株として用いたが，今後， 実際の発酵工程を想定した酵母や乳酸菌に対する代謝活性 モニタリング実験を行う予定である。

\section{謝 辞}

本研究の遂行にあたり, 誘電泳動技術に関する助言を頂 いた, 九州大学 末廣純也教授に謝意を表す。なお, 本研究 の一部は, 文部科学省科学研究費補助金 (No. 17760340) の 助成を受けて行われた。

(平成 20 年 4 月 7 日受付, 平成 20 年 7 月 24 日再受付)

$$
\text { 文献 }
$$

(1) M. Hakoda, Y. Wakazaki, S. Mii, and N. Kitajima : "Development of Dielectropholetic Filter for Viable-nonviable Cell Separation”, J. Inst. Electrostat. Jpn., Vol.29, No.1, pp.8-13 (2005) (in Japanese) 箱田 優・脇坂嘉一・三井信一・北島信義 :「生死細胞分離のための 誘電泳動フィルターの開発」, 静電気学会誌, 29, 1, pp.8-13 (2005)

(2) M. Suzuki, T. Yasukawa, H. Shiku, and T. Matsue : "Separation of Live and Dead Microorganisms in a Micro-Fluidic Device by Dielectrophoresis", The Japan Society for Analytical Chemistry, Vol.54, 
No.12, pp.1189-1195 (2005) (in Japanese)

鈴木雅登・安川智之・珠㺵 仁・末永智一：「誘電泳動法による微小 流体中での微生物の生死分離」, 分析化学, 54, 12, pp.1198-1195 (2005)

( 3 ) J. Suehiro, R. Yatsunami, R. Hamada, and M. Hara : "Quantitative estimation of biological cell concentration suspended in aqueous medium by using dielectrophoretic impedance measurement method", J. Phys. D: Appl. Phys., Vol.32, No.21, pp.2814-2829 (1999)

(4) J. Suehiro, R. Hamada, D. Noutomi, M. Shutou, and M. Hara : "Selective detection of viable bacteria using dielectrophoretic impedance measurement method", J. Electrostat., Vol.57, No.2, pp.157-168 (2003)

( 5 ) D. W. E. Allsopp, K. R. Milner, A. P. Brown, and W. B. Betts : "Impedance technique for measuring dielectrophoretic collection of microbiological particles", J. Phys. D: Appl. Phys., Vol.32, No.9, pp.1066-1074 (1999)

(6) 米澤岳志:「ビール， ウイスキー発酵の誘電計測によるオンラインモ ニタリング」, 生物工学, 78, pp.152-155 (2000)

( 7 ) K. Asami and T. Yonezawa : "Dielectric analysis of yeast cell growth", Biochim. Biophys. Acta, Vol.1245, No.1, pp.99-105 (1995)

( 8 ) K. Asami, T. Hanai, and N. Koizumi : "Dielectric Properties of Yeast Cells", J. Membrane Biol., Vol.28, No.1, pp.169-180 (1976)

(9) T. Enjoji, E. Amako, S. Uchida, and F. Tochikubo : "Analysis of Dielectric Characteristics for Injured Escherichia coli using Impedance Measurement method", J. Inst. Electrostat. Jpn., Vol.31, No.1, pp.8-13 (2007) (in Japanese)

円城寺隆治・尼子恵里・内田 諭・枋久保文嘉 :「インピーダンス計 測による損傷大腸菌の誘電特性解析」, 静電気学会誌, 31, 1, pp.8-13 (2007)

(10) H. A. Pohl : "Dielectrophoresis", Cambridge Univ. Press, New York (1978)

(11) 静電気学会 :「静電気ハンドブック」, オーム社 (1998)

(12) H. A. Pohl : "The motion and precipitation of suspensoids in divergent electric fields", J. Appl. Phys., Vol.22, No.7, pp.869-971 (1951)

(13) 末廣純也:「電気の力で細菌をキャッチ! 電気的手法による細菌の 簡易検出」，電学誌, 121, 8, pp.547-550 (2001)

（14）石原一彦・何 川・片桐祐司：「高精度バイオ検査を実現する表面処 理技術」，検査技術, 7, 10, pp.12-18 (2005)

(15) 森 良一・中山弘明・三㴊一二・光山正雄 :「微生物学」, 医学書院 (1991)

(16) F. Joux and P. Lebaron: "Use of fluorescent probes to assess physiological functions of bacteria at single-cell level", Microbes and Infection, Vol.2, No.12, pp.1523-1535 (2000)

(17) 天児和暢 - 小池聖淳 :「微生物学における電子顕微鏡技術 $[$ 上]」, 学 会出版センター (1982)

(18) 森地敏樹：「損傷菌ならびに貧栄養菌の特性およびこれらの菌の修 復・培養条件について 2 損傷菌の特性」, 防菌防徽, 34, 7, pp.429-437 (2006)

（19）土戸哲明：「加熱殺菌に置いて発生する損傷菌とその生理学」，防菌 防徽, 30, 2, pp.105-110 (2002)

(20) M. T. Madigan, J. M. Martinko, and J. Parker：「Brock 微生物学」, オ一 么社 (2003)

（21）土戸哲明・高麗寛紀・松岡英明・小泉淳一：「微生物制御」，講談社 (2002)

（22）土戸哲明・松村吉信：「殺菌・静菌における “ストレスバイオテクノ ロジー”とその概念」, 生物工学, 77, 6, pp.225-228 (1999)
(23) 土戸哲明・坂元 仁:「メンブレン・ストレスバイオテクノロジーと しての細胞膜損傷の誘発による殺菌とモニタリング」, 生物工学, 82, 5, pp.193 (2004)

(24) P. G. Jones, M. Mitta, Y. Kim, W. Jiang, and M. Inouye : "Cold shock induces a major ribosomal-associated protein that unwinds double-stranded RNA in Escherichia coli”, Proc. Natl. Acad. Sci., USA, Vol.93, pp.76-80 (1996)

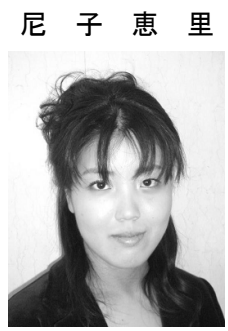

(非会員) 1982 年 2 月 13 日生。 2007 年 3 月東 京都立大学工学部電気工学科卒業。同年（株） 内田洋行情報システム事業部入社。現在に至 る。

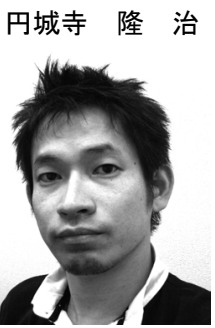

（非会員） 1970 年 2 月 5 日生。1993 年 3 月北 里大学衛生学部産業衛生学科卒業。同年（株） 重松製作所入社を経て, 2003 年 6 月エンテスト ジャパン（株）入社。2007 年 4 月首都大学東京 大学院理工学研究科電気電子工学専攻博士課 程入学。現在に至る。誘電泳動原理による微生 物計測システムに関する研究に従事。応用物理 学会, 静電気学会, 日本防菌防徽学会会員。

内 田諭 (正員) 1970 年 7 月 14 日生。1998 年 3 月北海

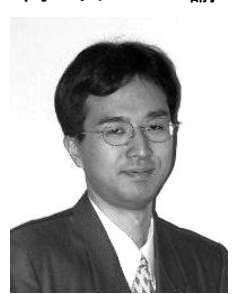
道大学大学院工学研究科電子情報工学専攻博 士課程中退。同年 4 月東京都立大学大学院工学 研究科助手, 2005 年首都大学東京大学院工学研 究科助教授, 2007 年同理工学研究科准教授, 現 在に至る。博士 (工学)。放電プラズマ及び微 小電気力学の基礎過程と応用に関する研究に 従事。応用物理学会，静電気学会会員。

朽久保 文 嘉

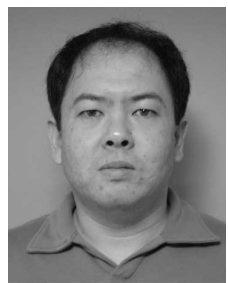

正員） 1965 年 2 月 14 日生。1992 年 3 月慶応 義塾大学大学院理工学研究科電気工学専攻博 士課程修了。同年 4 月東京都立大学大学院工学 研究科助手。1995 年同講師，2001 年同助教授， 2005 年首都大学東京大学院工学研究科助教授, 2007 年同理工学研究科准教授, 現在に至る。博 士 (工学)。放電プラズマの基礎過程と応用に 関する研究に従事。応用物理学会, 静電気学会 会員 